\title{
CLASSIFYING OBJECTS IN SPACE ACCORDING TO SOUTH AFRICAN PROPERTY LAW
}

\author{
W Erlank \\ LLB HonsBA LLM LLD \\ Associate Professor, North-West University \\ (Potchefstroom Campus)
}

\section{SUMMARY}

Traditionally, objects were classified according to their relation to man or according to their own nature. The classical division according to their relation to man relates to the question of whether something is susceptible to private ownership or not. This aspect is of cardinal importance when it comes to objects in space. This results in the need for a further distinction between things that are classified as being in commerce (res in commercium) and things that are outside of commerce (res extra commercium). After a thorough investigation it is determined that heavenly bodies, such as the Moon, as well as smaller bodies, such as asteroids, can be classified as objects of property law falling within commerce - if the required characteristics are present, and taking into consideration that the current prohibition on appropriation of heavenly bodies will either be discarded in future, or at the very least be interpreted in such a way as to allow for appropriation in certain instances. These characteristics are corporeality, external to persons, independence, appropriability/susceptibility to human control and use and value. Therefore it can be surmised that in terms of property law, it is possible to acquire ownership of heavenly bodies and other objects in space, and that these objects can be classified in terms of South African property law.

However, the following (from the conclusions) flows more satisfactorily for the author - one makes the choice:

By turning to the foundational aspects of property law as found in South African property law, large celestial bodies, such as the Moon, as well as smaller bodies, such as asteroids, can be classified as objects of property law falling within commerce - if the required characteristics (corporeality, external to persons, independence, appropriability/susceptibility to human control, use and value) are present. When these are present, it would follow that it would be possible to acquire a heavenly body, object in space, or part thereof by means of occupation of a res nullius. Even in cases where certain categories of things have been designated as being unappropriable, or outside of commerce (res extra commercium) due to historical reasons, the possibility exists that by exerting effective control over the object, it can be reclassified as being appropriable and hence inside of commerce (res in commercio). In addition to this classification of celestial bodies as falling inside of commerce and having the characteristics of objects, the discussion of their division according to their nature, being corporeal or incorporeal, movable or immovable, divisible and indivisible, consumable and non-consumable, fungible and non-fungible, and singular and composite, has revealed that even in terms of this classification, heavenly bodies could in fact fall squarely within the confines of property law, and can therefore be regarded as objects of property law even in cases where they do not fall into the narrow classification of "things". 


\section{$1 \quad$ INTRODUCTION $^{1}$}

With the realization and commencement of commercial spaceflight at the beginning of $2012,{ }^{2}$ it is perhaps fitting to return to some of the basic questions and assumptions about property in space in order to re-evaluate their worth in the new millennium. Currently property issues about objects in space are usually dealt with in terms of space law, which in turn is currently regulated as a part of international law. However, in quite a number of jurisdictions (including South Africa) space law also forms part of national law. Space law is also often equated to and theoretically discussed in the same breath as the law of the sea ${ }^{3}$ and the Antarctica treaty ${ }^{4}$ - however, although similar in many aspects, these areas of the law are unsuitable for developing space law, ${ }^{5}$ especially with regard to property in space. Therefore it is regarded mostly as being removed from the sphere of private law - which traditionally covers aspects of ownership. To put this into perspective, a quick review of the current space law regime will suffice.

There are five main international treaties that apply to space law. Of these treaties, the Treaty on Principles Governing the Activities of States in the Exploration and Use of Outer Space, including the Moon and Other Celestial Bodies of 1966 (also known as the Outer Space Treaty) is the most important ${ }^{6}$ with regard to dealing with property in outer space. ${ }^{7}$ In terms of

1 This article is based on a paper presented at the $30^{\text {th }} \mathrm{Bi}$-Annual Conference of the Classical Association of South Africa at the University of the Free State in Bloemfontein, 2013. Additional research and the writing of this article was completed while kindly hosted in 2015 by Prof JHM van Erp and the Faculty of Law, Maastricht University, Maastricht, the Netherlands.

2 Mann "The Year's Most Audacious Private Space Exploration Plans" 2012 Wired http://www.wired.com/2012/12/audacious-space-companies-2012/ (12 December 2012); Ferreira-Snyman "Legal Challenges Relating to the Commercial Use of Outer Space, with Specific Reference to Space Tourism" 2014 PER 2.

3 United Nations Convention on the Law of the Sea, 1982 (UNCLOS).

4 The Antarctic Treaty (1959) http://www.ats.aq/e/ats_keydocs.htm.

5 There are certain elements that can be compared in terms of international law, and it is beneficial to look at the public law and international law development in this area. However, the limited (if often unexplored) resources and area of the international zones in the high seas cannot be adequately equated to the actual boundlessness of space. In essence, the argument in terms of property law should not focus on the territorial boundaries of nations, but rather on the unique aspect of genuine res nullius existing in space. This will be discussed in more depth later in this article.

6 The Agreement Governing the Activities of States on the Moon and other Celestial Bodies (1979) (Moon Agreement aka Moon Treaty) is also often discussed in literature, since it attempted to explicitly prohibit private and national property rights on the Moon, however, it was never ratified by any of the main space powers and as such is generally regarded as a failed treaty. See in general: Marks "Who Owns Asteroids or the Moon?" 2012 NewScientist http://www.newscientist.com/article/mg21428670.200-who-owns-asteroids-or-the-moon. html (09 June 2012); and Reynolds "Who Owns the Moon? The Case for Lunar Property Rights" 2008 Popular Mechanics http://www.popularmechanics.com/science/space/moonmars/4264325 (09 June 2012).

7 The five main treaties are: Treaty on Principles Governing the Activities of States in the Exploration and Use of Outer Space, Including the Moon and other Celestial Bodies (1967) (Outer Space Treaty); Agreement on the Rescue of Astronauts, the Return of Astronauts and the Return of Objects Launched into Outer Space (1968); Convention on International Liability for Damage Caused by Space Objects (1972); Convention on Registration of 
the Outer Space Treaty, celestial bodies are regarded as the "property" of all of mankind, and national or sovereign ownership of such celestial bodies is prohibited.

The current legal position ${ }^{8}$ regarding ownership of celestial bodies set out in treaties that are essentially the product of a different age (being the Cold War). ${ }^{9}$ Many authors underline the need for the existing treaties to be developed and adapted to the modern needs of the civilized world. ${ }^{10}$ While originally promoting legal and political certainty in a time of crises, they fail to keep up with new developments in humankind's space faring capabilities, and the commencement of commercial access and participation in outer space. ${ }^{11}$ This fact has been recognised by a number of authors, and there is currently no consensus as to whether and to what extent private ownership of objects in space is either prohibited or allowed. ${ }^{12}$ Some authors argue that it is absolutely prohibited by current international law, ${ }^{13}$ while others have interpreted the existing conventions and practices as prohibiting sovereign ownership, while allowing for the existence of private ownership. ${ }^{14}$ There is also a third group of authors who advocate for the development of the international law to explicitly allow for the recognition of private property rights to objects in space. ${ }^{15}$ This group has been very vocal and active, and the new developments in space travel, exploration and exploitation have led to increased pressure from this group for the recognition of property rights in space. It is quite possible that international law will either develop proactively to embrace private ownership in space - driven by, amongst others, the economic needs of private and commercial investors in space. Instead, the focus will be on the property aspects of objects in space.

Objects Launched into Outer Space (1975); and Agreement Governing the Activities of States on the Moon and other Celestial Bodies (1979).

8 In terms of international law.

9 Blount "Renovating Space: The Future of International Space Law" 2011 Denver Journal of International Law and Policy 516.

10 See in general the discussion of the need to adapt in Ferreira-Snyman 2014 PER 38; and see also Blount 2011 Denver Journal of International Law and Policy 515.

11 See in general Dalton "Developing the Final Frontier: Defining Private Property Rights on Celestial Bodies for the Benefit of all Mankind" 2010 SSRN http://ssrn.com/ abstract=1660163 (27 May 2012) 12-16 and 25-26. Dalton argues that it is perhaps better to work within the confines of the already existing treaties so as to avoid high transaction costs.

12 Fountain "Creating Momentum in Space: Ending the Paralysis Produced by the 'Common Heritage of Mankind' Doctrine" 2002 Connecticut LR 1753-1754; Tinkang "These Aren't the Asteroids you are Looking for: Classifying Asteroids in Space as Chattels, not Land" 2012 Seattle University LR 561.

13 Freeland "Outer Space and the Non-appropriation Principle" in Smith (ed) The Ashgate Book on Property, Exclusion, and Sovereignty (2013) 97; and Zell "Putting a Mine on the Moon: Creating an International Authority to Regulate Mining Rights in Outer Space" 2006 Minnesota Journal of International Law 506-509.

14 Wasser and Jobes "Space Settlements, Property Rights, and International Law: Could a Lunar Settlement Claim the Lunar Real Estate it Needs to Survive?" 2008 Journal of Air Law \& Commerce 37; and Zullo "The Need to Clarify the Status of Property Rights in International Space Law" 2002 The Georgetown LJ 2413.

15 See Dalton "Developing the Final Frontier: Defining Private Property Rights on Celestial Bodies for the Benefit of all Mankind" 2010 SSRN http://ssrn.com/abstract=1660163 (27 May 2012); Fountain 2002 Connecticut LR 1753-1754; and Satler "Transporting a Legal System for Property Rights: From the Earth to the Stars" 2005 Chicago Journal of International Law 27. 
Since the current position is unclear, and there is a strong likelihood that the current position will change ${ }^{16}$ this article will investigate whether and how objects in space could by classified and characterised by reference to South African property law. Finally it should be noted that while space law is governed in terms of overarching international agreements and treaties, each country is expected to deal with a number of space related matters and their own citizens under national law, whether it be by promulgating new national space laws, or by adapting current laws to make provision therefore. ${ }^{17}$ As such, if South Africa in general and South Africans specifically, continue to participate in outer space endeavours, many property-related issues will need to be dealt with in terms of South African property law.

\section{OBJECTS IN SPACE}

\section{Introduction}

Before continuing with the classification of objects in space, perhaps one should enquire whether celestial real estate can in fact be classified as property. For example, many civil law jurisdictions accept that only tangible "things" or objects of property are accepted as objects of property law, and hence are objects to which one can claim ownership and other property rights. ${ }^{18}$ The Anglo-American tradition tends to not make such distinctions, and is regarded as having a "wider" meaning of "property" than the "narrow" thing-based civil law tradition. ${ }^{19}$ Therefore, in the next section the characteristics of things (objects) will be discussed, and objects in space will face the same scrutiny as their counterparts on Earth did, to determine whether a) they can be regarded as objects of property law, and b), whether ownership of such objects is a possibility. As such, the first section will consider the characteristics of a "thing" or object of property law, and the second section will look at the division of objects of property law according to their relation to man or according to their own nature. The division according to their relation to man is thé determining factor when it comes to deciding whether an object of property law is susceptible to private ownership or not.

16 See, eg, the position taken by the United States of America's Commission on Implementation of United States Exploration Policy which recommended a change to the current space law regime so as to ensure "appropriate property rights for those who seek to develop space resources and infrastructure". Satler 2005 Chicago Journal of International Law 23-24.

17 See in general Ferreira-Snyman 2014 PER 35 fn 216; United Nations "National Space Law" http://www.unoosa.org/oosa/en/ourwork/spacelaw/nationalspacelaw.html (14 June 2015); and Freeland "Fly me to the Moon: How will International Law Cope with Commercial Space Tourism?" 2010 Melbourne Journal of International law 106.

18 See Erlank Property in Virtual Worlds (2012) 213-215.

19 For purposes of this paper, when discussing property in space in terms of "things", it will mean that it will also be accepted under the Anglo-American tradition. 


\section{Characteristics of "things" 20}

\section{Corporeality $^{21}$}

In the civil law tradition, the first characteristic of a thing is that it is usually said to be corporeal or tangible. This entails that a thing can be observed with at least one of the five senses, and that it occupies a certain volume of space. $^{22}$ This restriction is due to both dogmatic and systemic reasons, but the restriction that a thing has to be corporeal depends on tradition and the prevailing notions in society, rather than on physics. ${ }^{23}$

Some legal systems in the civil law tradition ${ }^{24}$ do accept that certain forces of nature such as electricity and atomic energy, qualify as things because of the similarities they share with corporeal things. ${ }^{25}$ In contrast to this strict adherence to the principle of corporeality, several incorporeal things have been recognised in South African law. ${ }^{26}$ This recognition comes from both statute and case law, and occurs especially where the object of the real right is another subjective right. ${ }^{27}$

20 See generally Van der Merwe Sakereg (1989) 24; Du Bois Wille's Principles of South African Law (2007) 412; Van der Merwe and De Waal The Law of Things and Servitudes (1993) 12; and Badenhorst, Pienaar and Mostert Silberberg \& Schoeman's The Law of Property (2006) 14.

21 See generally Van der Merwe Sakereg 27; Du Bois Wille's Principles of South African Law 412; Van der Merwe and De Waal The Law of Things and Servitudes 13; and Badenhorst, Pienaar and Mostert Silberberg \& Schoeman's The Law of Property 14-19.

22 While certain forces of nature like gravity, heat, radioactivity, light, sound and electricity can be perceived by one of the senses, they are nevertheless said to be excluded from the definition of a thing in South African law because they cannot be described in terms of space. Van der Merwe and De Waal The Law of Things and Servitudes 13; and Badenhorst, Pienaar and Mostert Silberberg \& Schoeman's The Law of Property 14. See Nahrungsmittel GmbH v Otto 1993 (1) SA 639 (A); and Serva Ship Ltd v Discount Tonnage Ltd [2000] 4 All SA 400 (A).

23 Van der Merwe and De Waal The Law of Things and Servitudes 13. However, for a different view refer to the discussion above about the private law approach to property as the object of rights, where Cloete asserts that not only a narrow thing concept is accepted in South African private law. Cloete provides this differing view in his LLD dissertation, and illustrates how the prevailing notions of society can influence this restriction. See Cloete Onstoflike Sake in die Nuwe Suid-Afrikaanse Sakereg (2001) viii-ix and 318.

24 The French Civil Code Art 529 states that "Obligations and actions having as their object sums due or movable effects, shares or interests in financial, commercial or industrial concerns, even where immovables depending on these enterprises belong to the concerns, are movables by prescription of law." For Italian law see the Italian Civil Code Art 814 that accepts energy as an object of property rights. The Swiss Civil Code Art 713 deals with movable property, and includes forces of nature which can be brought under legal control and do not belong to land. According to German law, things were not always restricted to corporeals, but the position has changed since codification. Wieling Sachenrecht (2006) 54. Currently, $\S 90$ of the $B G B$ restricts things to corporeal objects (körperliche Gegenstände) and electricity (Energie) is not regarded as an exception to this rule. Wieling Sachenrecht 55. A similar approach was followed in the Netherlands but the position has changed after the current civil code was adopted. See Erlank Property in Virtual Worlds (2012) 5.2.2.3. Van der Merwe and De Waal The Law of Things and Servitudes 13.

26 Badenhorst, Pienaar and Mostert Silberberg \& Schoeman's The Law of Property 35.

27 Examples where incorporeal things have been recognised in case law include Le Riche $v$ PSP Properties CC [2005] 4 All SA 551 (C); Telkom SA Ltd v Xsinet (Pty) Ltd 2003 (5) SA 
In space, most objects of property that are of importance at the moment will be corporeal and tangible in some way or another. ${ }^{28}$

Tangibility on the other hand is an important consideration. While tangibility and corporeality are often used interchangeably, as far as property in space is concerned, tangibility does in fact once again (as it did in Roman law) ${ }^{29}$ become an important consideration. While not a decisive factor, the ability to touch an object in space will considerably improve the chances of appropriating such object (or part thereof), due to the requirements of control, use and value (discussed below).

\section{External to persons ${ }^{30}$}

The second characteristic of a thing is that it must be of an impersonal nature and external to man. ${ }^{31}$ In today's society, human beings are regarded as legal subjects only and never as legal objects. ${ }^{32}$ Although human corpses or parts of corpses could be classified as legal objects, this view will apply with the proviso that they fall outside of legal commerce. This will not have much of a bearing on property in space, since most objects in space will by default be external to persons. However, human bodies and derivatives thereof, such as hair and excreta, could become the topic of some interesting legal questions. For example, while it is currently considered part and parcel of space travel to recycle urine as drinking water, it has also been hypothesized that excrement could be converted into food, or at the very least be used as shielding or building material. ${ }^{33}$ In such a case, as soon as the urine or faeces (and other bodily ejecta) is separated from the person from whom it comes, it becomes objects of property law in space that have use and value - and which someone might want to appropriate (or steal).

309 (SCA); Graf v Buechel 2003 (4) SA 378 (SCA); and Ben-Tovin v Ben-Tovin 2001 (3) SA $1074(\mathrm{C})$.

28 As the field of "property (law) in space" develops as a discrete field of law, it is expected that corporeality and the reliance thereon will once again fade to the background, as it has done on Earth. Eg, things such as radio-frequency spectrum, line-of-sight access to solar power, as well as concessions and licences to operate space related services and activities, could all form part of new objects of property law in space.

29 Van der Merwe Sakereg 25; and Gai 2 13; I 2 2; D 1811.

30 See generally Du Bois Wille's Principles of South African Law 414; Van der Merwe and De Waal The Law of Things and Servitudes 13; Badenhorst, Pienaar and Mostert Silberberg \& Schoeman's The Law of Property 19; and Van der Merwe Sakereg 23.

31 Van der Merwe and De Waal The Law of Things and Servitudes 13.

32 This is in contrast to Roman times (amongst others) when certain human beings (usually slaves) were treated as things, Van der Merwe and De Waal The Law of Things and Servitudes 13. Space travel and the possible use of androids, self-aware artificial intelligence systems and related technologies, create the possibility of having ownership over these self-aware systems, since they will most probably be regarded as objects of property law. This translates to the possibility of having slaves in space.

33 For more on this see Roach Packing for Mars: The Curious Science of Life in the Void (2010) 265. 


\section{Independence ${ }^{34}$}

A thing must be a definite and distinct entity that can exist separately from anything else, and have a well-defined existence in space. ${ }^{35}$ Things such as running water, land, sand and gasses are not initially regarded as independent and need to be separated into manageable and recognisable entities by human activity before they are regarded as property objects falling within legal commerce. ${ }^{36}$ Immovable things come into being once they have been demarcated on a surveyor's plan, diagram, aerial photo or general plan and the plan is approved and registered in the Deeds Register ${ }^{37}$ while a building usually forms part of the land on which it is erected. $^{38}$ By analogy, in space it is also possible to use cartographic surveys of planets for defining immovable things. However, this will not necessarily be applicable to smaller objects such as smaller comets and asteroids. The question of independence could be used to help with the distinction between movables and immovables in space.

\section{Appropriability/Susceptibility to human contro/ ${ }^{39}$}

The fourth characteristic is that a thing must be capable of being subjected to human control. ${ }^{40}$ If an object is not susceptible to such control it would not qualify as a thing. Traditional examples of things that are not susceptible to human control were the celestial bodies such as the sun, moon, planets and even shipwrecks that lie inaccessible on the bottom of the ocean. ${ }^{41}$ Aspects of nature, such as the sea and air that are not separated into manageable units, are also not considered to be things. In terms of property in space, celestial bodies are now susceptible to human control. Even when they are not, by giving them independence through the use of human activity (such as collecting space dust), they become susceptible to human control and thus appropriable. However, the requirement of appropriability does mean that one will have to make a determination about this in terms of the division

34 See generally Du Bois Wille's Principles of South African Law 414; Van der Merwe and De Waal The Law of Things and Servitudes 14, where it is referred to as individuality; Badenhorst, Pienaar and Mostert Silberberg \& Schoeman's The Law of Property 14 and 21; and Van der Merwe Sakereg 25.

35 Van der Merwe and De Waal The Law of Things and Servitudes 14.

36 Van der Merwe and De Waal The Law of Things and Servitudes 14. This ties into the Lockean labour theory that is also very apt for explaining why ownership of celestial real estate should be allowed. Locke Two Treatises of Government (1690, Laslett P ed 1988) "Second Treatise of Government"; and Erlank Property in Virtual Worlds 144.

37 These requirements are contained in the Deeds Registries Act 47 of 1937 and the Land Survey Act 8 of 1997.

38 Badenhorst, Pienaar and Mostert Silberberg \& Schoeman's The Law of Property 20.

39 See generally Badenhorst, Pienaar and Mostert Silberberg \& Schoeman's The Law of Property 21; Du Bois Wille's Principles of South African Law 415; Van der Merwe and De Waal The Law of Things and Servitudes 14; and Van der Merwe Sakereg 26.

40 Badenhorst, Pienaar and Mostert Silberberg \& Schoeman's The Law of Property 20.

41 Owing to technological advances, this category will cease as man finds new and innovative ways to get access to and take control of these things, Van der Merwe and De Waal The Law of Things and Servitudes 14. 
according to the meaning of "something being inside or outside" of commerce. $^{42}$

\section{Use and value ${ }^{43}$}

The fifth and final characteristic of a thing is that it must be of use and value to legal subjects, and destined to meet the needs of a legal subject. ${ }^{44}$ If a legal subject has no use or value for a thing, no legal relationship can exist between a thing and a legal subject. An important consideration here is that the thing does not necessarily need to have economic value, as sentimental value is also regarded as sufficient to satisfy this requirement. ${ }^{45}$ To illustrate, one can use the example of a dead leaf in a garden. In a person's subjective evaluation, the leaf may not have any value and could constitute a nuisance. However, objectively evaluated, it may have value because it can be used as compost, for scientific study or even for arts and crafts. Because it is capable of satisfying someone's needs (objectively speaking) it is regarded as a thing. ${ }^{46}$ The same applies to celestial bodies. While most asteroids do not currently attract attention for being of value ${ }^{47}$ there are some that are indeed deemed to be exceptionally valuable for their mineral content or purely scientific interest. When creating a colony in outer space, it is possible that the colonists (especially those born in outer space and thus away from Earth) will have a purely sentimental attachment to the "ground" or "land" on which their new home is located.

\section{Conclusion}

With the exception of the requirement of corporeality, the requirements mentioned above should not stand in the way of the recognition of heavenly bodies as objects of property in space. Even then, the requirement of corporeality is also only an issue in a limited number of civil-law based jurisdictions, and should not be an issue in South African property law. Even in those jurisdictions it could be disregarded as an exception to the rule when it refers to heavenly bodies. This would mean that it would be very easy to accept most heavenly bodies as objects of property law, when they satisfy all five of the required characteristics of corporeality, external to persons, independence, appropriability/susceptibility to human control and use and value - as set out above.

42 See the discussion below.

43 See generally Du Bois Wille's Principles of South African Law 415; Van der Merwe and De Waal The Law of Things and Servitudes 15; Badenhorst, Pienaar and Mostert Silberberg \& Schoeman's The Law of Property 21; and Van der Merwe Sakereg 27.

44 Van der Merwe Sakereg 27.

45 Van der Merwe and De Waal The Law of Things and Servitudes 15. Sentimental value is also relevant when dealing with objects of property that contribute to human flourishing and personhood. See Radin "Property and Personhood" (1982) Stan LR 959-960; and Erlank Property in Virtual Worlds 165 and 168.

$46 \quad$ Van der Merwe Sakereg 27.

47 See Erlank "Rethinking terra nullius and Property Law in Space" 20157 PER 2513. 


\section{Traditional and alternative division of things}

\section{Introduction}

In the Roman and civil law tradition, ${ }^{48}$ things (objects) were traditionally classified according to their relation to man, or according to their own nature. $^{49}$ The division according to their relation to man relates to the question whether something is susceptible to private ownership or not. ${ }^{50}$ This results in the distinction between things that are in commerce ${ }^{51}$ (res in commercio $^{52}$ that can be traded or sold, and things that are outside of commerce (res extra commercium) that could not be traded or sold. ${ }^{53}$ Things outside of commerce are further divided into common things (res omnium communes), public things (res publicae), things belonging to corporate bodies (res universitatis) ${ }^{54}$ and religious thing ${ }^{55}$ (res divini iuris). ${ }^{56}$

The alternative division according to the nature of the objects, distinguishes between corporeals (res corporales) and incorporeals (res incorporales) ${ }^{57}$ single (res singulares) and composite things (res universales) $;{ }^{58}$ movables and immovables; ${ }^{59}$ replaceables (res fungibiles) and non-replaceables (res non fungibiles) $;{ }^{60}$ consumables (res

48 As opposed to the Anglo-American and Common law tradition. See in general Erlank Property in Virtual Worlds.

49 Van der Merwe Sakereg 27; and Badenhorst, Pienaar and Mostert Silberberg \& Schoeman's The Law of Property 24.

50 D 20312 ; and Van der Merwe and De Waal The Law of Things and Servitudes 15.

51 Things that can be privately owned, or be the objects of other real rights, Badenhorst, Pienaar and Mostert Silberberg \& Schoeman's The Law of Property 24.

52 In Roman law the division was made between res in patrimonio and res extra patrimonium. Van der Merwe Sakereg 28.

53 Things that are not susceptible to private ownership.

54 Van der Merwe Sakereg 28-29. Res universitatis is also sometimes mentioned under res in commercio, but in the context of an exception, res universitatis in commercio.

55 In Roman law.

56 Van der Merwe and De Waal The Law of Things and Servitudes 15; and Badenhorst, Pienaar and Mostert Silberberg \& Schoeman's The Law of Property 24.

57 The corporeality requirement of a thing is discussed above. See Van der Merwe Sakereg 36; Badenhorst, Pienaar and Mostert Silberberg \& Schoeman's The Law of Property 33-34; and Erlank Property in Virtual Worlds (2012) 244. This is also sometimes discussed under the heading of tangibles and non-tangibles. Van der Merwe Sakereg 27; Du Bois Wille's Principles of South African Law 412; Van der Merwe and De Waal The Law of Things and Servitudes 13; Badenhorst, Pienaar and Mostert Silberberg \& Schoeman's The Law of Property 14-19; and Erlank Property in Virtual Worlds 231.

58 Van der Merwe Sakereg 49; Van der Merwe and De Waal The Law of Things and Servitudes 21; and Erlank Property in Virtual Worlds 249.

59 Van der Merwe Sakereg 39; Badenhorst, Pienaar and Mostert Silberberg \& Schoeman's The Law of Property 34-39; and Erlank Property in Virtual Worlds 245.

$60 \quad$ Van der Merwe Sakereg 47. 
consumptibiles) and non-consumables (res non consumptibiles) ${ }^{61}$ and divisible and indivisible things. ${ }^{62}$

The next section will start with a discussion of the division according to the nature, of objects and how this applies to objects in space and then move on to the division of objects according to their relation to man. (The division will, however, be of importance when determining whether other rights, smaller objects and especially human made objects are objects of property law in space.)

\section{Division according to the nature of the objects}

\section{Corporeal and incorporeal things ${ }^{63}$}

As discussed above, corporeal things ${ }^{64}$ were those things that were tangible or perceivable by the external senses. Intangible things and rights were classified as incorporeal things. ${ }^{65}$ In property law, real rights and personal rights that function as objects of limited real rights are classified as incorporeal things. ${ }^{66}$ Property in space can also therefore be divided into corporeals and incorporeals. Corporeals will cover most of the objects in space, and will include planets, planetoids, comets, satellites and also some more nebulous objects such as cosmic dust. Incorporeals will include such objects as gas-based celestial real estate, including stars, gaseous-planets, radiation, solar power and other forms of energy. It could also include other forms of space related intellectual and intangible property, as well as rights serving as the objects of a property right. The question whether a gaseous planet or star, should be classified as corporeal or incorporeal could perhaps be answered with reference to the fact that because the gas is contained by the planet, or a star's gravity into a discernible and discrete whole, the object exhibits independence and therefore should be regarded as an object of property as an exception to the requirement of corporeality.

\section{Movable and immovable things}

Things are further classified as being either movable or immovable. ${ }^{67} \mathrm{~A}$ thing is considered to be a movable if it can be moved from one place to another

61 Van der Merwe Sakereg 48; Van der Merwe and De Waal The Law of Things and Servitudes 23; and Erlank Property in Virtual Worlds 248. Replaceables and consumables are sometimes used interchangeably, and often wrongly used interchangeably. See Van der Merwe Sakereg 49 fn 236.

62 Van der Merwe and De Waal The Law of Things and Servitudes 24; Van der Merwe Sakereg 49; and Erlank Property in Virtual Worlds 247.

63 See Van der Merwe Sakereg 36; and Badenhorst, Pienaar and Mostert Silberberg \& Schoeman's The Law of Property 33-34.

64 In the civil law tradition.

65 Badenhorst, Pienaar and Mostert Silberberg \& Schoeman's The Law of Property 33.

66 Ibid; Desai $v$ Desai 1993 (3) SA 874 (N). In the common law tradition, meanwhile, incorporeals are generally accepted as objects of property law.

67 Van der Merwe Sakereg 39; and Badenhorst, Pienaar and Mostert Silberberg \& Schoeman's The Law of Property 34-39. 
without damaging it or losing its identity. ${ }^{68}$ Immovable (corporeal) things are usually units of land, including all things that are permanently attached to the land. As a rule, all things that cannot be classified as immovables are classified as movables. ${ }^{69}$ The distinction between movable and immovable things is of special importance in the following circumstances: transfer of ownership; contracts to alienate immovable things; real security; and the sale of a debtor's assets in execution. ${ }^{70}$

The transfer of movables takes place by means of delivery of the thing to the receiver with the intention to transfer ownership. However, transfer of immovable things takes place by means of registration of the transfer in the deeds registry (also with the intention of transferring ownership). ${ }^{7}$

Both immovables and movables can be either corporeal or incorporeal. ${ }^{72}$ An example of a corporeal movable thing is any tangible thing that is not immovable, like a car or a computer. ${ }^{73}$

Traditionally speaking, objects of property law are usually divided into either movable or immovable property (with various subcategories of each). Generally this division does not create too much confusion, and one can readily accept that a car will be a movable and a house (or piece of land) will be immovable. Following this logic, one can make the analogy that spacecraft and satellites could be considered to be movables, while a lunar base or section of celestial real estate (it is hard not to use such contemporary words as land) will be considered to be immovable. However, what about celestial bodies in general - such as the Moon or Mars? What about an asteroid or comet? How does one define these objects in terms of property law? The answer to this distinction could be difficult since by their nature, all these bodies do move, as compared to a plot of land on Earth in relation to Earth. Analogous to the test or distinction between movables and

\footnotetext{
Van der Merwe and De Waal The Law of Things and Servitudes 24.

Van der Merwe Sakereg 42.

Van der Merwe and De Waal The Law of Things and Servitudes 28-29.

Van der Merwe and De Waal The Law of Things and Servitudes 28.

72 Badenhorst, Pienaar and Mostert Silberberg \& Schoeman's The Law of Property 34-35. An example of a corporeal immovable thing is a piece of land as indicated on a general plan and registered in the Deeds Office. Van der Merwe Sakereg 42. Real and personal servitudes in respect of immovable things can be regarded as incorporeal immovable things. Other examples of rights that acquire the character of incorporeal immovable property on registration against the title deed of land include: praedial and personal servitudes (like usufruct, use and habitation) over immovable property; a lease over immovable property that gives rise to a ius in re; grants and leases of mineral rights; charges on land; real actions for the vindication of registered immovable property; a fiduciary interest in immovable property; registered mortgages over immovable property; and other real rights, such as the right of occupation for a term of years, Van der Merwe and De Waal The Law of Things and Servitudes 26.

73 An incorporeal movable thing could be something like a share in a company. Other examples of incorporeal movable property include shares in a company; real rights having as their object a movable such as a pledge, notarial bond or a usufruct over movables; hypothecary rights in respect of a debt; any rights in personam which are connected with the transfer of movable property from one person to another or which can be satisfied by a money payment; dividends or other periodic payments not solely charged on land; the goodwill of a business; and patents, designs, trademarks and copyright and, in general all incorporeal things which are not considered to be movable, Van der Merwe and De Waal The Law of Things and Servitudes 26-27.
} 
immovables on Earth, the consideration will most probably be done by means of the ability of man to move any of these bodies outside of their normal orbits or trajectories. This would mean that for the moment only very small asteroids would be movable. Larger objects would be immovable. In other words, the question will be whether any object in space is movable by man or not. Even though they move by themselves, the fact that man cannot influence of change this movement, will designate them as "celestial immovables".

\section{Divisible and indivisible things}

A divisible thing can be divided into smaller components while retaining its nature and function, without the smaller components losing their proportional value. $^{74}$ An example is a piece of land that can be divided into smaller pieces. Generic movables like a volume of building sand are also divisible. An indivisible thing cannot be divided into smaller pieces without changing the value, nature or function of the thing. ${ }^{75}$ An example of this would be a piece of furniture like a chair. The same will apply to plots of land on planets, moons and even some large asteroids, which can be subdivided. Indivisible things in space will invariably include mostly man-made objects. It could be possible to change the identity of an object, such as an asteroid if it were to be broken up into pieces so small as to lose its identity. For example by pulverising an asteroid into gravel, the asteroid could lose its identity. It will not be an asteroid anymore, but rather a collection of space debris. Alternatively, by breaking of pieces of an asteroid through (for example) mining, the asteroid will maintain its identity, while the broken off pieces will lose their identity and become something else, like, for example, gravel.

\section{Consumable and non-consumable things}

Consumable things, such as wine, bread and fast food are either consumed or depleted through their normal use. Non-consumable things, like houses and cars essentially remain the same if used normally and are only subject to normal wear and tear. ${ }^{76}$ When consumables are destroyed by normal use, they can usually be replaced with a similar thing if the consumed thing had been borrowed or leased. The distinction is important for the following reasons. ${ }^{77} \mathrm{~A}$ usufruct can be given only regarding non-consumable things because of the requirement that the object of the usufruct must be kept and returned to the owner in the same condition (salva rei substantia). However, a quasi-usufruct can be given regarding consumable things if the holder of the right is compelled to return things of the same amount and quality as had been consumed. Money is regarded as a consumable thing and a quasiusufruct can be given in respect of it. In space, this will become an issue in cases of mining operations that take place on someone else's property. In

74 Van der Merwe Sakereg 49.

75 Van der Merwe and De Waal The Law of Things and Servitudes 24; and Van der Merwe Sakereg 49

76 Van der Merwe Sakereg 48.

77 Van der Merwe and De Waal The Law of Things and Servitudes 23. 
matters pertaining to activities, such as creating rocket fuel out of minerals and processed water, ${ }^{78}$ the minerals would be considered to be consumables.

\section{Fungible and non-fungible things}

Fungible things belong to a certain generic class of things that can be replaced by any other similar thing. ${ }^{79}$ They do not have any characteristics that make them so unique as to be considered irreplaceable. A ream of copier paper can just as easily be replaced with another similar ream of paper. In trade, fungible things are often referred to in terms of weight, measure or number. Non-fungible things are considered irreplaceable because they have unique characteristics or value. Examples are original paintings or hand crafted Fabergé Easter eggs. A fungible thing may become a non-fungible thing in certain circumstances, for example due to sentimental reasons. Money is considered a fungible thing. In space if one were to use an asteroid as base station for refuelling operations, one asteroid of the same general size and location would serve just as well as another, and will therefore be fungible. However, if the asteroid contains a specific valuable combination of minerals that another asteroid does not, the asteroid will not be a fungible.

\section{Singular and composite things}

Things are either singular or composite. ${ }^{80}$ Singular things can exist independently without being composed of any other distinct components (like a piece of wood, wine glass, compact disk, asteroid or moon rock). ${ }^{81}$ Composite things are composites of various independent things that have lost their individuality due to being either organically or mechanically united into a single entity. ${ }^{82}$ Examples include a motor car, laptop computer satellite, spacecraft and moon buggy. It would also include rocket fuel.

A distinction is made between the composite thing and the individual components of which it comprises. Composite things comprise of the following elements: a principal thing, accessory thing, auxiliary thing and fruits. ${ }^{83}$ Principal things are capable of independent existence from the composite thing, and can be the objects of real rights. ${ }^{84}$ The component of a composite thing that provides the thing with its identity is considered the principal thing. ${ }^{85}$ This would be the case with something, such as the International Space Station (ISS). This means that the owner of the principal thing is also the owner of the composite thing, even if it includes accessory

78 See Erlank "Rethinking terra nullius and Property Law in Space" 20157 PER 2513.

79 Van der Merwe Sakereg 43; and Van der Merwe and De Waal The Law of Things and Servitudes 22.

80 Van der Merwe Sakereg 49; and Van der Merwe and De Waal The Law of Things and Servitudes 21.

Van der Merwe Sakereg 49.

82 Van der Merwe and De Waal The Law of Things and Servitudes 21.

83 Van der Merwe Sakereg 51.

84 Badenhorst, Pienaar and Mostert Silberberg \& Schoeman's The Law of Property 41.

85 Khan $v$ Minister of Law and Order 1991 (3) SA 439 (T). 
and auxiliary things that have acceded to the principal thing. Examples include a motor car, keyboard or hairdryer. The example of the ISS does raise some interesting legal questions. While comprising of different parts and modules belonging to different sovereign nations, it does have a principle identity. The question then will be who the owner of the main identity is. ${ }^{86}$

An accessory thing can exist independently of the principal thing, but has merged with or been mixed with the principal thing, with the result of losing its independence ${ }^{87}$ An example of an accessory thing will be a brick that is built into the wall of a house, or a memory chip installed into a laptop. The separate component modules of the ISS are examples of this. While initially independent of one another, as soon as they were incorporated into and bolted onto the rest of the space station, they lost their independent identity, thus becoming accessory things.

An auxiliary thing can exist separately from the principal thing and has not acceded to it physically. However, because of its economic value, destination or use, it is no longer regarded as an independent thing for the purposes of property law. ${ }^{88} \mathrm{~A}$ physical connection with the principal thing is not necessary. An example of this is the key to a house, or a set of driver disks sold with a laptop computer. In space, this could include space suits, remote operated vehicles and even control keys (codes) for satellites. ${ }^{89}$

Fruits are things that are produced by the principal thing without the destruction or consumption of the principal thing. ${ }^{90}$ Fruits are regarded as accessory to the principal thing before they are separated, but are always destined to be separated and to exist independently. Examples include natural fruits like fruit of trees, plants, as well as organic and inorganic things that renew themselves like milk or wool. Another example is civil fruits like interest on capital, rent or dividends on shares. ${ }^{91}$ In terms of mining in space, minerals will naturally not be considered to be fruits, since in all but a few cases minerals do not renew themselves (are non renascentia). ${ }^{92}$ One could

86 While the ISS partner states rely on an international agreement that each State retains ownership and control of their separate sections, this does not provide for a suitable property based answer of who owns the space station as a whole. While interesting, this issue will not be addressed further in this article. See ESA "International Space Station legal framework" ESA http://www.esa.int/Our_Activities/Human_Spaceflight/International_Space_ Van der Merwe Sakereg 51.

88 Van der Merwe Sakereg 52.

89 Much like where any person who knows the access details to a bank account, email address, or website URL (uniform resource locator) can be regarded as the owner, and ownership passes by means of delivery of the access details from the old owner to the new. In cases such as these, where the thing is considered to be an intangible movable (the satellite is a tangible moveable, but after launch it effectively becomes intangible since it is destined to be used and controlled remotely), possession of the access codes effectively equals ownership, since everyone who does not have these control codes is excluded from over the object.

Van der Merwe Sakereg 54.

91 Van der Merwe Sakereg 56.

92 On Earth, eg, salt is still considered to be a self-renewing mineral. 
perhaps consider things such as electricity generated by orbiting solar electricity farms to be the fruit of those plants.

\section{Division according to their relation to man}

\section{Negotiable things (res in commercio)}

Negotiable things are susceptible to private ownership, and are further categorised as either being owned by a person or not owned by a person. ${ }^{94}$ Examples of the first type are things owned by a natural or legal person, or things in a deceased or insolvent estate (res alicuius). ${ }^{95}$ The second type refers to things that are capable of being owned but that are not owned at a particular stage by anyone (res nullius). Examples of this are wild animals, birds and fish that are wild by nature and have not been owned by anyone. Ownership of these things may be acquired by appropriation. There are three categories of res nullius, namely things that have never been privately owned (such as wild animals) before their capture; wild animals, birds and bees that have regained their freedom and ceased to be owned privately; and things that have been abandoned with the intention ${ }^{96}$ to relinquish ownership, and are no longer within the physical control of their owners (res derelictae). ${ }^{97}$ Ownership of these things may also be acquired either through original or derivative means. In space, however, at the moment it will most often occur in terms of occupatio (appropriation) of (for example) a res nullius. ${ }^{98}$

93 See Hornyak "Farming Solar Energy in Space" 2008 Scientific American http://www.scientificamerican.com/article/farming-solar-energy-in-space/ (14 April 2015); Energy Matters "Solar power farms in space - a step closer" 2009 http://www.energymatters.com.au/renewable-news/em574/ (14 April 2015); Templeton "Japan's 25-year Plan to put a Gigawatt Solar Power Farm in Space" 2014 http://www.extremetech.com/extreme/181389-japans-25-year-plan-to-put-a-gigawatt-solarpower-farm-in-space (14 April 2015).

94 See in general Van der Merwe Sakereg 278; and Badenhorst, Pienaar and Mostert Silberberg \& Schoeman's The Law of Property 31-33.

95 Van der Merwe Sakereg 29.

96 If the owner does have the intention of still being owner of such a thing, but has lost the thing and is no longer in physical control of it, it is called a res deperditae, and in this case the thing cannot be acquired by another person by means of appropriation, Badenhorst, Pienaar and Mostert Silberberg \& Schoeman's The Law of Property 33.

97 This is an interesting scenario, especially when it comes to man-made satellites. While many satellites are clearly either non-operational and abandoned - with the associated issues of contributing to space debris and even endangering other satellites, space craft, astronauts and the ISS, governments tend to be aggressively territorial about these abandoned objects. They quite happily abandon them (either when they have broken down, catastrophically failed or reached the end of their operational lives), but do not want them to fall into anybody else's hands. The reasons behind this include possible (illegal) weaponised systems or trade, state or military secrets, such as launch codes for missile systems, amongst others. This duality of effectively abandoning these inoperational satellites, while still trying to assert ownership via exclusion, should be mitigated by new conventions to allow for (at the very least) appropriation for the sake of cleaning up the orbital space. Else, if governments do not wish to allow this, they should be required to actively ensure that the inoperational satellites are deorbited within a specified time frame after having become inoperational.

98 See the discussion later in this article. 
According to Roman law, if someone took possession of a res nullius with the intention to become the owner - he or she acquired ownership of the res. ${ }^{99}$ While in modern South African law the situation is similar in that

"appropriation or occupation (occupatio) may be defined as the (unilateral) taking of possession by a person of an unowned thing (res nullius) - that is, of a corporeal movable or immovable thing within the sphere of private law (res in commercio) which is not in the ownership of another person - with the
intention of becoming owner".

Res nullius in this sense literally means "something belonging to no-one", but is also often defined as "things which are capable of being owned, but which are in fact owned by nobody", ${ }^{101}$ or "those things which, although susceptible to private ownership, do not belong to anyone at a particular point in time". ${ }^{102}$ As such, in terms of law, res nullius had the extra requirement of being something that is capable of being owned.

However, in order for someone to effectively acquire and keep ownership of a res nullius, there is an important requirement that the new owner needs to be able to exercise effective control of the thing. In other words, the owner needs to have also possession or physical control of the thing. ${ }^{103}$ These aspects of possession and physical control are of cardinal importance, and requirements for classifying a thing as being appropriable and inside of commerce. ${ }^{104}$ When applied to the scenario of outer space, effective control is also of cardinal importance. Outer space is boundless, ${ }^{105}$ unexplored and unappropriated by man. Outer space, as well as all the heavenly bodies contained therein, collectively forms the epitome of res nullius. This makes it easier to reconcile oneself with the Lockean property (labour) theory ${ }^{106}$ of recognizing property rights over property that belongs to no-one, and one can easily argue that objects in outer space are res nullius or terra nullius. ${ }^{107}$ This is also tied to another important consideration, since when appropriation of land on Earth by means of occupation is considered, there is always the question of whether the land in fact belongs to no-one. The argument is made that in most circumstances unallocated property within the

99 Thomas, Van der Merwe and Stoop Historical Foundations of South African Private Law (1998) 167.

100 Badenhorst, Pienaar and Mostert Silberberg \& Schoeman's The Law of Property 137.

101 Thomas, Van der Merwe and Stoop Historical Foundations of South African Private Law 167.

102 Badenhorst, Pienaar and Mostert Silberberg \& Schoeman's The Law of Property 32.

103 Van der Merwe Sakereg 25-26.

104 See the discussion below.

105 For all practical purposes and especially for dealing with property theory.

106 Locke Two treatises of government (1690, Laslett ed 1988) "Second treatise of government"; and Erlank Property in Virtual Worlds 144.

107 This use of terra nullius should not be confused with the theory (or excuse) of colonisation of foreign territory, as applied especially to the (discovery) of Australia, amongst others. This has been dealt with profusely in literature and case law, with the most well-known case being the Mabo case. See Mabo v State of Queensland (1992) 175 C.L.R. 1. When using terra nullius in terms of property law in space, the literal meaning is implied, ie Earth belonging to no-one. However, since terra nullius properly refers to Earth, one can refer to such objects of property as being luna nullius, astra nullius or maybe even caelestia nullius. See Erlank "Rethinking terra nullius and Property Law in Outer Space" 20157 PER 2514. 
boundaries of a country belongs to the State. ${ }^{108}$ This is of course not a problematic aspect when it comes to "land" in space, where land will be truly unowned and as such res nullius.

\section{Non-negotiable things ${ }^{109}$ (res extra commercium)}

Non-negotiable things cannot be privately owned, and as such fall outside of the commercial sphere. There are four prominent types of such things. Firstly, there are common things that are common to all people, but at the same time belong to no-one. ${ }^{110}$ Examples of this include natural resources that fall outside of legal commerce and that are available to all people, for example free air and running water (res omnium communes). ${ }^{111}$ Public things constitute the second example of non-negotiable things. These are things owned by the State, and used directly for the benefit of the public (res publicae). ${ }^{112}$ Examples include public roads, national parks and the beach. ${ }^{113}$ Not all State property falls outside of commerce, since State land and buildings are usually negotiable. The third type of non-negotiable thing relates to things belonging to corporate bodies (res universitatis) and not to individual persons. ${ }^{114}$ Examples include objects of property, like markets, theatres, guildhalls and churches that belong to municipalities and statutory boards. Generally, these types of corporate bodies are juristic persons according to public law and not private law. ${ }^{115}$ The last type of nonnegotiable thing in this category is called religious things (res divini iuris), and used to be outside of commerce. ${ }^{116}$ This position has changed after the Reformation when all such things became susceptible to private ownership. ${ }^{117}$

Of special interest for property in space is res omnium communes. ${ }^{118}$ The language of the space law conventions tends to use such phrases as

108 Badenhorst, Pienaar and Mostert Silberberg \& Schoeman's The Law of Property 140.

109 As discussed in Van der Merwe Sakereg 27; and Badenhorst, Pienaar and Mostert Silberberg \& Schoeman's The Law of Property (2006) 31-33.

110 Badenhorst, Pienaar and Mostert Silberberg \& Schoeman's The Law of Property 25.

111 Van der Merwe Sakereg 30.

112 Van der Merwe Sakereg 31.

113 Badenhorst, Pienaar \& Mostert Silberberg \& Schoeman's The Law of Property 25.

114 Even though this category of things is still listed and discussed in the pre-eminent South African property law books, the relevance and existence of the category in modern property law is questionable. See Van der Merwe Sakereg 28; Mostert and Pope The Principles of the Law of Property in South Africa (2010) 31; Badenhorst, Pienaar and Mostert Silberberg \& Schoeman's The Law of Property 29-30; and Van der Merwe and De Waal The Law of Things and Servitudes 16.

115 Van der Merwe and De Waal The Law of Things and Servitudes (1993) 16; and Badenhorst, Pienaar and Mostert Silberberg \& Schoeman's The Law of Property 30.

116 Van der Merwe Sakereg 35.

117 Badenhorst, Pienaar and Mostert Silberberg \& Schoeman's The Law of Property 30.

118 For interesting discussions on the principles of res extra commercium, res nullius and the accompanying principles and history as it applies to space law (especially from an AngloAmerican perspective), see Fruchterman "Introduction to Space Law" 1965 JAG Journal 14; Cherian and Abraham "Concept of Private Property in Space - An Analysis" 2007 Journal of International Commercial Law and Technology 215-217; Listner "The Ownership and Exploitation of Outer Space: A Look at the Foundational Law and Future Legal Challenges to Current Claim" 2003 Regent Journal of International Law 77-78; and Dalton "Developing 
"province of all mankind" and "benefit and interests of all countries", ${ }^{119}$ in addition to the fact that ownership, both private and sovereign, is prohibited. In keeping with the purport of the conventions, the essence of res omnium communes is that these are objects, held in common, for the use of and by everyone. The space law conventions do not take into regard the fact that in Roman law the reason for something being classified as being outside of commerce (res extra commercium) was often due to the requirement that something (an object) must be appropriable by humans, or subject to human control. ${ }^{120}$ With this in mind, things such as free flowing water, breathable air and heavenly bodies (amongst other things) were defined as objects of property law that fell outside of commerce (res extra commercium), and as such were not capable of being appropriated by private individuals. ${ }^{21}$ Since celestial bodies were viewed abstractly, the possibility of reaching them has never even been considered, ${ }^{122}$ and therefore no-one would ever be able to appropriate or control a heavenly body. Hence, the relegation of these bodies to res extra commercium.

However, there has always been exceptions that allowed for things classified as being outside of commerce, to be reclassified as being inside of commerce. As technology allowed, more and more of these things were recategorised. Free flowing water could be collected in a bucket, and the same could be said for sand in the sea. Breathable air can now be compressed and used for (amongst other things) SCUBA diving. These things were once clearly not subject to human control or private ownership, ${ }^{123}$ but by using technology to contain and control a specified volume of the water or air, one can (and could) acquire ownership of it. ${ }^{124}$ Badenhorst, Pienaar and Mostert sets the position out as follows:

"Common things (res omnium communes) are those things which by natural law are common to all persons, but belong to no-one. However, although a common thing in its entirety is not susceptible to private ownership, it is nevertheless possible to acquire ownership of a specific portion thereof, for example when air is compressed in a gas cylinder and thus reduced to a thing in commerce."

The determining factor is that the unspecified and uncontrolled object has to be collected or removed from the general whole and then subjected to human control. ${ }^{126}$ Once this had been done, the water or air was quantified, specifiable and subjectable to human control. The same principle now applies to heavenly bodies. While heavenly bodies in general are regarded

the Final Frontier: Defining Private Property Rights on Celestial Bodies for the Benefit of all Mankind" 2010 SSRN http://ssrn.com/abstract=1660163 (27 May 2012) 9-10.

119 Outer Space Treaty Article I.

20 Van der Merwe Sakereg 30.

121 Van der Merwe Sakereg 26.

122 Apart from in myths. Think of (eg) the story of Icarus. Although, even in the myth of Icarus, it was clear from the outset that man was never destined to reach the sun.

123 And therefore belonged to everyone.

124 Van der Merwe Sakereg 25 and 30.

125 Badenhorst, Pienaar and Mostert Silberberg \& Schoeman's The Law of Property (2006) 25 (footnotes omitted).

126 By bottling, collecting it in a bucket or in some other form of containment. Van der Merwe Sakereg 25-26. 
to be res omnium communes (by international law), the argument is that as with other forms of re omnium communes, if one can exert control over a heavenly body, one will acquire a recognizable property right or interest ${ }^{127}$ in it.

\section{CONCLUSION}

From the discussion above, it should be clear that by turning to the foundational aspects of property law as found in South African property law, large celestial bodies, such as the Moon, as well as smaller bodies such as asteroids, can be classified as objects of property law falling within commerce - if the required characteristics are present, and taking into consideration that the current prohibition on appropriation of heavenly bodies will either be discarded in future, or at the very least be interpreted in such a way as to allow for appropriation in certain instances. These characteristics are corporeality, external to persons, independence, appropriability / susceptibility to human control and use and value. When these are present, it would follow that it would be possible to acquire a heavenly body, object in space, or part thereof by means of occupation of a res nullius. Even in cases where certain categories of things have been designated as being unappropriable or outside of commerce (res extra commercium) due to historical reasons, the possibility exists that by exerting effective control over the object, it can be reclassified as being appropriable and hence inside of commerce (res in commercio).

In addition to this classification of celestial bodies as falling inside of commerce and having the characteristics of things, the discussion of their division according to their nature, being corporeal or incorporeal; movable or immovable; divisible and indivisible; consumable and non-consumable; fungible and non-fungible; and singular and composite; has revealed that, even in terms of this classification, heavenly bodies could in fact fall squarely within the confines of property law, and can therefore be regarded as objects of property law even in cases where they do not fall into the narrow classification of "things".

127 If something is not traditionally protected by a property (law) right as an object of property law, it is still possible that it can be regarded as being a property-like interest that is protected (by contract or law) in such a way as to simulate a property right. For a discussion of the distinctions between property, property rights and property interests, and property-like protection see Erlank Property in Virtual Worlds 212, 227 and 304. 